\title{
Memahami Sifat Shiddiq Nabi Muhammad SAW Perspektif Bisnis Syariah
}

\author{
Oleh; \\ Nafiuddin \\ Institut Agama Islam Shalahuddin al-Ayubbi Bekasi \\ ghady729@gmail.com
}

\begin{abstract}
The Qur'an is very concerned about ethics in business. The people of Medina are people who often cheat in measuring and weighing, so Allah SWT decreases the surat of al-Mutaffifin as a threat to those who cheat in business. Siddiq is very closely related to business ethics. Siddiq in modern business ethics is often understood by the word "integrity". Integrity is an essential principle in business. Integrity itself is a way of upholding the values and ethics of business. The values and ethics in doing business clearly have a big contribution in doing business. Integrity in business alone must be invested in someone who wants to run a business or is running a business. Business people must make this integrity a basic principle in their business.Siddiq (integrity, honesty) is defined as the basis of speech, beliefs and actions based on Islamic teachings. So that it can be concluded that the nature of Siddiq is still very relevant to modern business ethics, or in other languages that the nature of Siddiq is universal business ethics meaning that it does not recognize the basic values underlying the ethics.
\end{abstract}

\section{Keyword: siddiq, ethics, business}

\section{A. PENDAhULUAN}

Islam sebagai the way of life merupakan pedoman dalam menjalankan kehidupan manusia dari segala aspek guna memperoleh kebahagiaan dunia dan akhirat. Salah satu di dalamnya adalah adalah aspek mu'amalah. Kata mu'amalah secara sederhana dapat didefiniskan sebagai kegiatan yang menyangkut hubungan antar manusia. Sebagai contoh kegiatan mu'amalah antara lain; sewa menyewa, berdagang, berbisnis, dll. Lebih lanjut Zakki (2002: 16) menjelaskan bahwa kegiatan mu'amalah dibagi menjadi dua; pertama mu'amalah yang berkaitan dengan kebutuhan hidup manusia yang bertalian dengan materi dan inilah yang dinamakan dengan ekonomi, sedangkan yang kedua, kegiatan mu'amalah yang terkait dengan pergaulan hidup yang dipertalikan oleh kepentingan moral rasa kemanusiaan dan inilah yang dinamakan sosial.

Dengan demikian Islam telah mengajarkan bahwa kegiatan ekonomi tidak dapat dilepaskan dari nilai-nilai dasar yang telah ditetapkan dalam al-Qur'an dan Hadist. Dalam hal ini kegiatan ekonomi konvensional juga dibicarakan dalam ekonomi syariah, yaitu upaya manusia dalam mendapatkan dan mengatur harta material ataupun non material dalam rangka memenuhi kebutuhan hidup sebagai individu maupun secara kolektif yang menyangkut produksi, distribusi dan konsumsi, hanya saja dalam ekonomi syariah harus didasarkan pada norma dan tata aturan ajaran Islam yang terdapat dalam al-Qur'an maupun hadist (Idri, 2015: 6).

Al-Qur'an memuat beberapa ayat yang menyinggung tentang norma atau etika bisnis, diantaranya adalah dalam QS al-Mutaffifin/ 83: 1-3 yang artinya: "Kecelakaan besarlah bagi orang-orang yang curang, yaitu orang-orang yang apabila menerima takaran dari orang lain mereka minta dipenuhi dan apabila mereka menakar dan menimbang untuk orang lain mereka mengurangi." 
Allah SWT melalui ayat tersebut di atas memberikan aturan main pada praktekpraktek ekonomi (jual-beli) yang dilakukan manusia, bahwa segala bentuk kecurangan atau penipuan menjadi kerugian yang besar bagi pelaku ekonomi itu sendiri. Selanjutnya Allah SWT pada QS. An-Nisa'/4:29 yang artinya:"Hai orang-orang yang beriman janganlah kamu saling mamakan harta sesamamu dengan jalan yang batil, kecuali dengan jalan perniagaan yang berlaku dengan suka sama suka diantara kamu. Dan jangan lah kamu membunuh dirimu sesungguhnya allah adalah maha penyayang kepadamu".

Kata bisnis dalam al-Qur'an, biasanya yang digunakan adalah tijarah, al-bai' tadayantum, dan isytara. namun kata yang sering digunakan adalah tijarah yang bermakna berdagang. Selain istilah tersebut masih banyak lagi term lain yang berkaitan dengan bisnis, seperti dayn, amwal, rizq, syirkah, dharb, dan sejumlah perintah melakukan perdagangan (Qs. Jumu'ah/ 62:9).

Dari uraian di atas dapat dipahami bahwa kegiatan bisnis tidak bebas nilai sebagaimana dipahami oleh kapitalis. Menurut Ricard T. De George dikutip oleh Mardatillah (2013: 93) bahwa antara bisnis dan moral tidak ada kaitannya apa-apa dan karena itu, merupakan kekeliruan jika aktivitas bisnis dinilai dengan menggunakan tolak ukur moralitas.

Al-Qur'an sangat menekankan etika dalam berbisnis. Allah SWT menegur langsung orang-orang Madinah melalui surat al-Mutaffifin, Diketahui secara umum bahwa orangorang Madinah termasuk orang-orang yang paling curang dalam menakar dan menimbang, maka Allah SWT menurunkan surat al-Mutaffifin sebagai ancaman bagi orang yang berbuat curang dalam kegiatan bisnis. Sedangkan surat yang kedua menegaskan tentang ketentuan dalam jual beli yang harus dilakukan suka sama suka, tidak boleh dengan cara yang batil termasuk eksploitasi dan pemaksaan. Salah satu kondisi yang harus dihilangkan dalam menciptakan 'an taraadhin minkum adalah terbebasnya transaksi jual beli dari proses penipuan (Khaeriyah, 2013: 153).

Selain itu terdapat beberapa ayat dalam al-Qur'an yang membahas secara eksplisit tentang etika bisnis, antara lain bahwa al-Qur'an banyak memotivasi manusia untuk melakukan kegiatan bisnis (Qs.Jumu'ah/ 62:10) dan terhindar dari rasa curiga dan penipuan bisnis, seperti keharusan membuat adminitrasi transaksi kredit (Qs.al-Baqarah/ 2:282), hal yang tidak kalah penting adalah memenuhi janji dalam bisnis (Qs. al-Maidah/ 5: 1).

Nabi Muhammad SAW sebagai manusia yang pilihan yang memiliki kepribadian yang menarik. Kepribadian yang menarik tersebut tergambar pada hadist-hadist Rosulullah, yaitu berupa ucapannya, tindakannya atau persetujuannya sangat erat kaitannya dengan etika bisnis. Tentunya begitu banyak hadits yang bersinggungan etika bisnis pedoman para sahabat dalam kegiatan bisnis pada masa itu. Di lain sisi Muhammad sebelum diangkat menjadi Nabi sudah dikenal oleh penduduk mekkah saat itu memiliki sifat-sifat terpuji, antara lain jujur (shiddiq), dapat dipercaya (amanah), cerdas dan bijaksana (fathanah), menyampaikan (tabligh). Dalam hal ini nampak pada serangkaian kegiatan bisnis beliau.

Muhammad berdagang dengan menonjolkan karakteristik yang unik yakni akhlakul karimah. Ada banyak nilai-nilai yang dapat dipetik dari perilaku bisnis rosul yang memikat yaitu; kejujuran, kepercayaan, spirit, bisnis yang benar-benar bersih, beretikat, berprospek cerah, rajin, mandiri, pantang menyerah, kuat yang selalu siap mengambil keputusan pada saat-saat sulit dan memiliki pribadi yang egaliter (Situpu, 2016:25). 
Perilaku Muhammad SAW tersebut menjadi hal yang sangat menarik untuk dibahas terutama sifat shiddiq Nabi dimanaMuhammad sebagai pelaku bisnis telah melekat sifat tersebut pada diri beliau padahal belum mengemban tugas sebagai uswatun hasanah. Untuk itu pada tulisan ini akan fokus pada sifat shiddiq dalam perspektif etika bisnis.

\section{B. KAJIAN PUSTAKA}

1. Sifat Nabi Muhammad

a. Siddiq (jujur atau benar)

Jujur nilai dasarnya adalah integritas, ikhlas, terjamin dan keseimbangan emosional adalah sikap yang sanggat urgent dalam hal bisnis. Jujur berarti melandaskan ucapan, keyakinan serta perbuatan berdasarkan ajaran Islam. Selalu bersikap jujur adan mengantarkan seseorang pada surganya Allah SWT. sebagiamana Rasullullah bersabda yang artinya :"Sesungguhnya kejujuran mengantarkan pada kebaikan dan kebaikan akan mengantarkan ke dalam surga. Seseorang yang selalu berusaha untuk jujur akan dicatat oleh allah sebagai orang jujur dan jauhilah oleh kamu perbuatan dusta, karena dusta akan mengantarkan pada kejahatan. Dan kejahatan akan mengantar kedalam neraka. Seorang yang selalu berdusta akan dicatat oleh allah sebagai pendusta."

b. Amanah (terpercaya)

Sikap amanah adalah nilai dasarnya terpercaya, dan nilai-nilai dalam berbisnisnya ialah adanya kepercayaan, bertanggung jawab, transparan, dan tepat waktu sikap ini juga sangat dianjurkan dalam aktifitas bisnis. Kejujuran dan amanah mempunyai hubungan yang sangat erat, karena jika seseorang telah dapat berlaku jujur pastilah orang tersebut amanah (terpercaya). Maksud amanah adalah mengembalikan hak apaa saja kepada pemiliknya, tidak mengambil sesuatu melebihi haknya dan tidak melebihi hak orang lain (Qardhawi: 2011, 177).

c. Fatonah (Cerdas)

Fatonah berarti memiliki pengetahuaan luas, nilai dalam bisnis memiliki visi, pemimpin yang cerdas sadar produk dan jasa serta mengerti akan sesuatu dan dapat menjelaskannya. Kecerdasan yang dimaksudkannya ini bukan hanya kecerdasan intelektual tapi juga kecerdasan emosional dan kecerdasan spritual seperti yang dikatakan Ary Ginanjar sebagai berikut kemampuan untuk memberi makna ibadah terhadap setiap perilaku kegiatan melalui langkah-langkah dan pemikiran yang bersifat fitrah, menuju manusia seutuhnya dan memiliki pola pemikiran tauhid serta berprinsip hanya karena Allah (Ginanjar, 2000: 34).

d. Tabligh (Komunikatif-Promotif)

Nabi Muhammad sebagai Rosul terakhir dikaruniai sifat tabligh untuk menyampaikan apa yang perintah oleh Allah kepada umatnya dengan tidak mengurangi sedikitpun perintah yang diterimanya.Sifat tabligh nilai dasarnya adalah komunikatif dan nilai bisnisnya adalah supel.

2. Pengertian etika

Etika berasal dari latin ethius (dalam bahasa yunani disebut ethos) yang dalam bentuk tunggalnya mengandung banyak makna antara lain, kebiasaan, akhlak, watak, sikap, cara berfikir (Hulaimi, 20017: 20). Sedangkan secara terminologi etika berarti pengetahuan yang membahas baik buruk atau benar-tidaknya tingkah laku dan tindakan manusia serta sekaligus menyoroti kewajiban-kewajiban manusia (Haris,2007:23). Dengan bahasa lain etika bagi seorang individu terwujud dalam 
kesadaran moral yang memuat keyakinan benar tidaknya sesuatu. Perasaan yang muncul bahwa ia akan salah bila melakukan sesuatu yang diyakininya tidak benar, berangkat dari norma-norma moral dan perasaan self-respect bila ia meninggalkannya, maka tindakan itu harus ia pertanggungjawabkan pada dirinya sendiri.

Kata bisnis sering dipahami sebagai aktifitas yang melibatkan penyediaan barang dan jasa yang diperlukan atau yang diinginkan oleh orang lain dengan prinsip kepuasan atas pelanggan atau konsumen (Irawan, 2017: 17). Jadi etika dalam dunia bisnis diperlukan untuk menjaga hubungan baik dan fairness dalam dunia bisnis. Sehingga dapat disimpulkan bahwa tujuan etika bisnis adalah untuk melarang perilaku bisnis, manajer perusahaan, pekerja yang seharusnya tidak dilakukan. Etika bisnis mempengaruhi bagaimana perusahaan berhubungan dengan pekerjanya, bagaimana pekerja berhubungan dengan perusahaan dan bagaimana perusahaan berubungan dengan mitra bisnisnya.

Untuk memahami perkembangan etika bisnis De George (dalam Irawan, 2017: 22-

23) membedakannya kepada lima periode di antaranya sebagai berikut:

1. Pada awal sejarah filsafat, plato, aristoteles dan filosof-filosof yunani lain menyelidiki bagaimana sebaiknya mengatur kehidupan manusia bersama dalam negara dan membahas bagaimana kehidupan ekonomi dan kegiatan niaga harus diatur. Pada masa itu masalah moral disekitar ekonomi dan bisnis disoroti dari sudut pandang teologi.

2. Masa peralihan; tahun 1960-an pada masa itu terjadi perkembangan baru yaang dapat disebut sebagai persiapan langsung bagi timbulnya etika bisnis. Ditandai pemberontakan terhadap kuasa dan otoritas di amerika serikat, revolusi mahasiswa. Pada saat itu juga timbul anti konsumerisme. Hal ini memberi perhatian pada dunia pendidikan khususnya manajemen, yaitu memasukkan mata kulia baru ke dalam kurikulum dengan nama busines and society and coorporate sosial responsibility.

3. Etika bisnis lahir di amerika serikat pada tahun 1970-an terdapat dua faktor yang mendorong kelahiran etika bisnis pada tahun 1970-an yaitu, sejumlah filosof mulai terlibat dalam memikirkan masalah-masalah etis disekitar bisnis dan etika bisnis dianggap sebagai suatu tanggapan tepat atas krisi moral yang sedang meliputi dunia bisnis. Pada saat itu mereka bekerja sama khususnya dengan ahli ekonomi dan manajemendalam meneruskan tendensi etika terapan.

4. Etika bisnis meluas ke eropa: tahun 1980 -an di eropa barat. Etika bisnis sebagai ilmu baru mulai berkembang kira-kira 10 tahun kemudian. Hal ini ditandai dengan semakin banyaknya perguruan tinggi dieropa barat yang mencantumkan mata kuliah etika bisnis.

5. Etika bisnis menjadi fenomena globa: tahun 1990-an etika bisnis telah hadir di amerika latin, asia, eropa timur dan kawasan dunia lainnya. di jepang yang aktif melakukan kajian etika bisnis adalah institute of moralogy pada universitas reitaku. Di india etika bisnis di praktekkan oleh menagement center of human values yang didirikan oleh dewan dereksi dari indiaan institute of menagement di kalkuta pada tahun 1992.

6. Hingga saat ini etika bisnis telah berkembang di Indonesia pada beberapa perguruan tinggi, terutama pada program pascasarjana telah diajarkan mata kulaih etika bisnis selain itu muncul organisasi yang melakukan kajian khusus 
tentang etika bisnis misalnya lembaga studi dan pengembangan etika usaha Indonesia (LSPEU Indonesia) di Jakarta.

Menurut Hulaimi (2017: 22), etika bisnis syariah adalah seperangkat prinsip dan norma berbasiskan al-Qur'an dan Hadist yang harus dijadikan pedoman oleh semua pedagang dalam aktivitas bisnis, baikbisnisskalabesardanskalakecil.

Al-Qur'an mengajarkan bahwa pada dasarnya Allah telah menyuruh manusia untuk bekerja. Manusia dianjurkan untuk melakukan kegiatan bekerja untuk memenuhi kebutuhan hidupnya, Nabi Muhammad merekomendasikan salah satu pekerjaan yang banyak mendatangkan rejeki adalah melakukan kegiatan bisnis. Bisnis dalam Islam dijelaskan melalui kata tijarah yang memilki dua makna, yaitu pertama perniagaan secara umum yang mencakup perniagaan manusia dengan Allah. Misalnya berjuang di jalan Allah dengan harta dan jiwanya, melaksanakn perintah Allah, menafkahkan hartanya di jalan Allah. Makna tijarah yang kedua adalah perniagaan secara khusus yaitu perdagangan sesama manusia (Fauzia, 2013: 7-8).

Dalam menjalankan kegiatan bisnisnya Allahswt. telah menjelaskannya melalui firmanNya padasuratal Baqarah ayat 62, yang artinya:"Sesungguhnya orang- orang Mukmin, orang-orang Yahudi, orang-orang Nasrani dan orang- orang Shabiin, siapa saja di antara mereka yang benar- benar beriman kepada Allah, hari kemuadian dan beramal shaleh, mereka akan menerima pahala dari Tuhan mereka, tidak ada kekhawatiran terhadap mereka, dan tidak ( pula) mereka bersedih hati."

Selain surat di atas ada beberapa dalil Al Qur'an yang menjelaskan hal serupa, yaitu:QS At Taubah: 105, yang artinya:"Dan katakanlah: Bekerjalah kamu, maka Allah dan Rasulnya serta orang- orang mu'minakan melihat pekerjaanmu, dan kamu akan dikembalikan kepada (Allah) Yang Maha Mengetahui akan yang ghaib dan yang nyata, lalu diberitakan-Nya kepada kamu apa yang telah kamu kerjakan."

Termasuk QS Al Baqarah :198, yang artinya:" Tidak ada dosa bagimu untuk mencari karunia (rezeki hasil perniagaan) dari Tuhan- Mu. Maka apabila kamu telah bertolak dari Arafah, berzikirlah kepada Allah Masy'arilharam. Dan berzikirlah ( dengan menyebut) Allah sebagaimanayang ditunjukanNya kepadamu, dan sesungguhnya kamu sebelum itu benar- benar termasuk orang-orang yang sesat."

QS An Nissa:29, yang artinya:"Hai orang- orang yang beriman, janganlah kamu saling memakan harta sesamamu dengan jalan yang bathil, kecuali dengan jalan perniagaanyang berlaku dengan suka sama suka antara kamu. Dan janganlah kamu membunuh dirimu, sesungguhnya adalah Allah Maha Penyayang kepadamu."

QS Faathir: 29, yang artinya:"Sesungguhnya orang- orang yang selalu membaca kitab Allahdan mendirikan shalat dan menafkahkan sebagian dari rezeki yang Kami anugerahkan kepada mereka dengan diam- diam dan terang- terangan,mereka itu mengharapkan perniagaan yang tidak merugi."

QS Al Jumu'ah: 10-11, yang artinya:" Apabila telah ditunaikan shalat, maka bertebaranlah kamu di muka bumi, dan carilah karunia Allah dan ingatlah Allah sebanyakbanyaknya supaya kamu beruntung. Dan apabila mereka melihat perniagaan atau permainan, mereka bubar dan menuju kepadanya dan mereka tinggalkan kamu sedang berdiri ( berkhotbah): "Katakanlah apa yang di sisi Allah adalah lebih baik daripada permainan dan perniagaan," dan Allah adalah sebaik-baik pemberi rezeki."

QS An Najm: 132, yang artinya:" Dan bahwasanya seorang manusia tiada memperoleh selain apa yang telah diusahakannya. Dan bahwasanya usahanya itu kelak 
akan diperlihatkan (kepadanya). Kemudian akan diberi balasan kepadanya dengan balasan yang paling sempurna."

QS Al An'am :132, yang artinya:"Dan tiap- tiap orang memperoleh deajat- derajat (seimbang)dengan apa yang dikerjakannya. Dan Tuhanmu tidak lengah dari apa yang mereka kerjakan."

QS As Shaf: 10-11, yang artinya:" Hai orang- orang yang beriman, sukakah kamu Aku tunjukkan suatu perniagaan yang dapat menyelamatkan kamu dari azab yang pedih? ( yaitu) kamu beriamn kepada Allah dan RasulNya dan berjihad di jalan Allah dengan harta dan jiwamu, itulah yang lebih baik bagimu, jika kamu mengetahui."

Dari beberapa ayat di atas, dapat diketahui bahwa tujuan bisnis menurut al-Qur'an adalah untuk mendapatkan dua keuntungan, keuntungan duniawi dan ukhrawi (Fauzia, 2013: 12). Hal ini menjadi pembeda utama antara bisnis syariah dan binis non syariah sebagaimana penjelasan secara detail berikut ini(Fauzia, 2013: 13):

\begin{tabular}{|c|c|c|c|}
\hline No. & Karakteristik Bisnis & Bisnis Islam & Bisnis non Islam \\
\hline 1. & Asas & $\begin{array}{l}\text { Akidah Islam ( nilai- nilai } \\
\text { transendental) }\end{array}$ & $\begin{array}{l}\text { Sekulerisme ( niali- niali } \\
\text { materialisme) }\end{array}$ \\
\hline 2. & Motivasi & Dunia akhirat & Dunia \\
\hline 3. & Orientasi & $\begin{array}{l}\text { Profit, zakat, dan benefit } \\
\text { (non } \\
\text { materi),pertumbuhan, } \\
\text { keberlangsungan, dan } \\
\text { keberkahan }\end{array}$ & $\begin{array}{l}\text { Profit, pertumbuhan, dan } \\
\text { keberlangsungan }\end{array}$ \\
\hline 4. & Etos Kerja & $\begin{array}{l}\text { Tinggi, bisnis adalah bagian } \\
\text { dari ibadah }\end{array}$ & $\begin{array}{ll}\text { Tinggi ,bisnis adalah } \\
\text { kebutuhan duniawi }\end{array}$ \\
\hline 5. & Sikap Mental & $\begin{array}{l}\text { Maju dan produktif, } \\
\text { konsekuensi keimanan dan } \\
\text { manifestasi kemusliman }\end{array}$ & $\begin{array}{ll}\text { Maju dan } & \text { produktif } \\
\text { sekaligus } & \text { konsumtif, } \\
\text { konsekuensinya } & \text { aktualisasi } \\
\text { diri } & \end{array}$ \\
\hline 6. & Keahlian & $\begin{array}{l}\text { Cakap dan ahli di } \\
\text { bidangnya, konsekuensi } \\
\text { dari kewajiban seorang } \\
\text { muslim }\end{array}$ & $\begin{array}{l}\text { Cakap dan ahli di bidangnya, } \\
\text { konsekuensi dari motivasi } \\
\text { punishment dan reward }\end{array}$ \\
\hline 7. & Amanah & $\begin{array}{l}\text { Terpercaya dan } \\
\text { bertanggungjawab, tujuan } \\
\text { tidak menghalalkan segala } \\
\text { cara }\end{array}$ & $\begin{array}{l}\text { Tergantung kemauan } \\
\text { individu ( pemilik capital), } \\
\text { tujuan menghalalkan segala } \\
\text { cara }\end{array}$ \\
\hline 8. & Modal & Halal & Halal dan haram \\
\hline 9. & Sumber Daya Manusia & $\begin{array}{lll}\text { Sesuai } & \text { dengan } & \text { akad } \\
\text { kerjanya } & & \end{array}$ & $\begin{array}{l}\text { Sesuai dengan akad } \\
\text { kerjanya atau sesuai dengan } \\
\text { keinginan pemilik modal }\end{array}$ \\
\hline 10. & Sumber Daya & Halal & \\
\hline 11. & Manajemen Strategic & $\begin{array}{l}\text { Visi dan misi organisasi } \\
\text { terkait erat dengan misi } \\
\text { penciptaan manusia di } \\
\text { dunia }\end{array}$ & $\begin{array}{l}\text { Visi dan misi organisasi } \\
\text { ditetapkan berdasarkan } \\
\text { pada kepentingan material } \\
\text { belaka }\end{array}$ \\
\hline 12. & $\begin{array}{l}\text { Manajemen } \\
\text { Operasional }\end{array}$ & $\begin{array}{l}\text { Jaminan halal dari setiap } \\
\text { masukan, proses dan }\end{array}$ & $\begin{array}{l}\text { Tidak ada jaminan halal bagi } \\
\text { setaip masukan, proses, }\end{array}$ \\
\hline
\end{tabular}




\begin{tabular}{|l|l|l|l|}
\hline & & $\begin{array}{l}\text { keluaran, mengedepankan } \\
\text { produktivitas dalam } \\
\text { koridor syariah }\end{array}$ & $\begin{array}{l}\text { dan keluaran } \\
\text { mengedepankan } \\
\text { produktivitas dalam koridor } \\
\text { manfaat }\end{array}$ \\
\hline 13. & Manajemen Keuangan & $\begin{array}{l}\text { Jaminan halal bagi setiap } \\
\text { masukan, proses, dan } \\
\text { keluaran keuangan, } \\
\text { mekanisme keuangan } \\
\text { dengan bagi hasil }\end{array}$ & $\begin{array}{l}\text { Tudak ada jaminan halal } \\
\text { bagi setiap masukan, proses } \\
\text { dan keluaran keuangan, } \\
\text { mekanisme keuangan } \\
\text { dengan bunga }\end{array}$ \\
\hline 14. & $\begin{array}{l}\text { Manajemen } \\
\text { Pemasaran }\end{array}$ & $\begin{array}{l}\text { Pemasaran dalam koridor } \\
\text { jaminan halal }\end{array}$ & $\begin{array}{l}\text { Pemasaran menghalalkan } \\
\text { segala cara }\end{array}$ \\
\hline Manajemen SDM & $\begin{array}{l}\text { SDM profesional dan } \\
\text { berkribadian Islam, SDM } \\
\text { adalah pengelola bisnis, } \\
\text { SDM bertanggungawab } \\
\text { pada diri, pemimpin, dan } \\
\text { Allah pdalah aktor produksi, SDM } \\
\text { bertanggung jawab pada } \\
\text { diri dan pimpinan }\end{array}$ \\
\hline
\end{tabular}

\section{PEMBAHASAN}

Sejarah telah mencatatpengalamanpertama kali Muhammad sebagai seorang pedagang, pada waktu itu Muhammad baru berusia 12 tahun dan melakukan perjalanan dagangnya yang pertama ke Syria bersamapamannya Abu Thalib, untuk selanjutnya Muhammad tumbuh dewasa dan mendapat pelajaran bisnis di bawah asuhan pamannya (Afzalurrahman: 2000, 6).

Rasulullah SAW sebagai pedagang yang sangat sukses pada masanya, dalam menjalankan bisnis perdagangannya Rasulullah sangat memperhatikan etika dalam berbisnis, di antanya adalah (Malahayati, 2010: 74):

1. Kejujuran dalam menjelaskan produk

Ketika melakukan sebuah transaksi jual beli atau transaksi bisnis seorang pedagang dianjurkan untuk bersikap jujur. Kejujuran menjadi modal utama dalam menjalankan sebuah bisnis. Jika kejujuran digunakan sebagai dasar etika menjalankan bisnis akan memberikan dampak yang positif bagi usaha bisnis yang dijalankan dan memberikan keuntungan bagi bisnis tersebut. Salah satu sifat kejujuran adalah kejujuran dalam menjelaskan sebuah produk yang ditawarkan. Seorang pebisnis harus jujur mengenai barang dagangannya baik dalam bentuk kualitas atau kuantitas sebuah barang. Dalam menjalankan bisnisnya Rasulllah SAW melarang kita meletakkan barang yang busuk di bawah barang yang masih baru. Rasulullah juga bersabda, yang artinya :"Tidak dibenarkan seorang muslim menjual satu jualan yang mempunyai aib, kecuali ia menjelaskan aibnya." ( HR Al Quzwani)

Dari hadist tersebut dapat dipahami betapa pentingnya sebuah kejujuran dimiliki oleh seseorang dalam hal apapun, termasuk kegiatan bisnis, karena seseorang yang selalu bersikap jujur akan selalu mendapatkan kepercayaan dari orang lain, dan tidak menutup kemungkinan dengan bersikap jujur mengenai produk yang ditawarkan, maka pelanggan akan terus berdatangan dan menjalin kerjasama. Hal tersebut tentu akan memberikan pengaruh terhadap bisnis yang dikelola, dan membuatnya terus berkembang dan maju. 
2. Suka sama suka

Etika bisnis yang juga diajarkan oleh Rasulullah adalah adanya prinsip suka sama suka antara kedua belah pihak yang melakukan transaksi bisnis. Prinsip tidak adanya paksaan dalam melakukan sebuah transaksi dapat memberikan keuntungan dalam mengelola sebuah bisnis. Seorang pebisnis selayaknya memahami pentingnya etika bisnis dan mengetahui bahwa prinsip suka sama suka memilki peran yang besar sebagai kunci sebuah kesuksesan bisnis.

3. Tidak menipu takaran, ukuran dan timbangan

Dalam melakukan kegiatan bisnis khususnya dalam bisnis perdagangan, seseorang dianjurkan untuk tidak menipu takaran, ukuran dan timbangan. Kegiatan bisnis yang baik adalah kegiatan yang dilakukan dengan landasan kejujuran dalam mengukur kadar timbangan dalam berdagang.

4. Tidak menjelek-jelekkan bisnis orang lain

Salah satu hal yang dilakukan seorang pebisnis dalam memperkenalkan produknya, salah satunya adalah dengan mengiklankan produk dagangannya. Etika yang harus dilakukan ketika mengiklankan produk adalah tidak meremehkan produk lain. Untuk mendapatkan keuntungan dalam kegiatan bisnis hendaknya etika bersikap sportif dan lebih menonjolkan keunggulan produk yang dimilki akan lebih mendatangkan keuntungan dan keberkahan bagi sebuah bisnis daripada menjelekjelekkan produk orang lain.

5. Bersih dari unsur riba

Keuntungan yang diperoleh dari sebuah bisnis hendaknya tidak mengandung unsur riba. Untuk meminimalisir unsur riba dalam usaha bisnis, hendaknya dalam berbisnis seseorang menggunakan cara- cara yang Islami yaitu tetap berpegang teguh dengan ajaran Al Qur'an dan Sunnah. Telah dijelakan dalam Al Qura'an bahwa riba sangat dilarang dalam Islam, berikut beberapa ayat yang menegaskan pelarangan riba :QS Ar Ruum ayat 39, yang artinya :" Dan sesuatu riba ( tambahan) yang kamu berikan agar dia menambahpada harta manusia, maka riba itu tidak menambah pada sisi Allah. Dan apa yang kamu berikan berupa zakat yang kamu maksudkan untuk mencapai keridhaan Allah, maka (yang berbuat demikian) itulah orang-orang yang melipatgandakan pahala."

Dari ayat tersebut telah jelas bahwa riba sangat dilarang dalam bisnis karena hanya akan mendatangkan kerugian bagi orang yang memakan riba tersebut. Oleh karena itu etika bisnis yang baik sangat dianjurkan untuk mendatangkan keuntungan yang bersifat duniawi dan ukhrawi.

6. Tidak menimbun barang ( Ihtikar)

Penimbunan barang dalam bisnis juga dilarang dalam Islam. Hal tersebut dikhawatirkan dapat memberikan kerugian bagi pihak lain karena akan menimbulkan kelangkaan suatu barang tertentu yang mengakibatkan naiknya harga barang sehingga menyebabkan orang lain mendapatkan kesulitan dalam memperoleh barang. Praktek ikhtikar biasanya dilakukan oleh pihak tertentu untuk mendapatkan keuntungan yang berlipatganda tanpa memperdulikan nasib orang lain. Oleh karena itu etika bisnis yang baik salah satunya adalah tidak melakukan penimbunan barang dan selalu memberikan manfaat atau kemudahaan bagi orang lain sehingga tercipta kemaslahatan.

7. Tidak melakukan monopoli 
Etika bisnis secara Islam juga menganjurkan kepada kita untuk tidak melakukan monopoli barang. Jika monopoli terjadi dalam suatu tempat akan menyebabkan barang menjadi sedikit karena disediakan oleh satu perusahaan saja sehingga menyebabkan harga barang menjadi mahal, hal tersebut tentu saja akan menyebabkan orang lain kesulitan karena tidak semua orang mampu membayar atau membeli barang dengan harga yang mahal.

8. Mengutamakan kepuasan pelanggan

Kepuasan pelanggan menjadi kunci yang tidak kalah penting untuk dilakukan dalam sebuah bisnis. Kepuasan yang dirasakan oleh seorang pelanggan akan membuat pelanggan untuk menggunakan dan membeli lagi produk atau jasa yang ditawarkan. Selain itu jika seorang pelanggan merasa puas dengan pelayanan atau produk yang ditawarkan maka pelanggan tersebut akan mengajak orang lain untuk menggunakan produk atau jasa dari perusahaan tersebut sehingga jika hal tersebut terus dilakukan akan dapat memberikan dampak yang positif dalam perusahaan.

9. Membayar upah sebelum kering keringat karyawan

Upah atau gaji adalah balas jasa yang diterima atas apa yang telah dilakukan atas suatu pekerjaan tertentu. Etika bisnis dalam Islam mengajarkan untuk membayar gaji karyawan sebelum keringatnya kering merupakan suatu perumpamaan bahwa pebisnis berkewajiban menyegerakan pembayaran upah seorang karyawan atau pegawai segera setelah pekerjaannya selesai dilakukan.

10. Teguh menjaga amanah

Etika profesi yang terakir adalah seorang pebisnis harus teguh dalam menjaga amanahnya. Menjaga amanah dalam hal ini dapat berarti banyak hal misalnya saja dalam menjalin hubungan kerjasama bisnis dengan rekan kerja hendaknya memilki sikap amanah atau dapat dipercaya. Ketika menjalin perjanjian bisnis hendaknya dituliskan dengan sebuah akad yang jelas sehinggga dapat dipertanggungjawabkan di kemudian hari. Sikap amanah dapat mempengaruhi kepercayaan seseorang atau mitra bisnis untuk menjalin kerjasama bisnis dengan perusahaan.

Dari penjelasan di atas, etika bisnis sangat luas cakupannya untuk mengantarkan pebisnis meraih keuntungan dunia akhirat. Menurut Yusuf Qardhowi (2001), prinsip etika bisnis syariah adalah sebagai berikut:

a. Akidah; dengan ada nya penyerahan diri kepada allah maka pelaku bisnis akan selalu menjaga perbuatannya dari hal-hal yang dilarang oleh syariah.

b. Shiddiq; sifat sidiq mendorong rasa tanggung jawab atas segala perbuatan dalam hal kegiatan mu'amalah.

c. Fathonah; sifat ini mendorong kearifan berfikir dan bertindak sehingga keputusan yang dihasilkan menunjukkan profesionalisme.

d. Amanah; hubungan bisnis yang dilandasi sifat amanah memunculkan kepercayaan yang merupakan modal dasar dalam kegiatan bisnis.

e. Tabligh; memampuan berkomunikasi menunjukkan proses menyampaikan sesuatu untuk mempengarui orang lain melalui perkataan yang baik.

f. Tidak melakukan praktek bisnis yang bertentangan dengan syariah, seperti : produk dan jasa yang haram, gharar, gabn, tadlis, riba, ihtikar.

Menurut Adinugraha (2013, 53-56) empat sifat nabi dikategorikan salah satu prinsip bisnis yang disebut dengan prinsip nubuwwah.Prinsip ini menegaskan bahwa nabi Muhammad merupakan model ideal dalam segala perilaku, termasuk juga perilaku bisnis yang seyogyanya dapat diteladani serta diimplementasikan oleh setiap manusia, 
khususnya pelaku bisnis. Sehingga tidak heran jika beliau memiliki empat sifat yang sering dijadikan landasan dalam aktivitas manusia sehari-hari termasuk juga dalam aktivitas bisnis, selain bidang leadership ia juga berpengalaman dalam bidang bisnis.

Empat sifat nabi yang dimaksud adalah shiddiq (benar, jujur, valid). Sifat shidiq akan memunculkan sifat efektifitas dan efisiensi. Efektifitas dimaksudkan untuk mencapai tujuan yang tepat dan benar sedangkan efisiensi adalah melakukan aktifitas dengan benar dan hemat.Maksudnya menggunakan teknik dan metode yang tidak menyebabkan kemubadhiran. Amanah (responsibility, dapatdipercayakredibilitas).Sifat ini dapat membentuk pribadi yang kredibel dan memiliki sikap penuh tanggung jawab.Sifat amanah memiliki posisi yang fundamental dalam aktifitas bisnis, karena tampak redibilitas dan tanggung jawab dalam berprilaku maka kehidupan bisnismenjaditidakstabil.Fathonah (kecerdasan, kebijaksanaan, profesionalisme,intelektualitas). Implikasi sifat ini dalam aktifitas bisnis adalah bahw asegala aktifitas harus dilakukan dengan ilmu atau kecerdasan dan optimalisasi semua akal yang ada untuk mencapai tujuan.Tabligh (komunikatif, transparansi, marketeble).Sifat tabligh dalam bisnis menurunkan prinsip-prinsip ilmu komunikasi (personal, interpersonal), seperti penjualan, pemasaran, periklanan, pembentukan opini masa, yang dilakukan dengan benar dan proposional.

Menurut shihab kata shiddiqmerupakan bentuk hiperbola dari kata shidq/benar, yakni orang yang selalu benar dalam sikap, ucapan, dan perbuatan. Pengertian bahwa apapun dan kapanpun selalu benar dan jujur, tidak ternodai oleh kebathilan, selalu tampak di pelupuk matanya yang haq. Selain itu pula shiddiq berarti orang yang selalu membenarkan tuntunan ilahi dengan membenarkan melalui ucapan yang dibuktikan dengan pengamalan (shihab, 2007: jilid 7, 458).

Kata shiddiq dalam etika bisnis moderen sering dibahasakan melalui kata integritas. Integritas merupakan prinsip esensial dalam bisnis.Integritas sendiri merupakan cara bagaimana menjunjung tinggi nilai-nilai dan etika dalam berbisnis. Nilai dan etika dalam berbisnis ini jelas memiliki andil yang besar dalam berbisnis.Integritas dalam berbisnis sendiri harus ditanamkan pada seseorang yang ingin menjalankan bisnis ataupun sedang menjalankan bisnis. Pelaku bisnis harus menjadikan integritas ini menjadi sebuah prinsip dasar dalam menjalankan bisnisnya.Dimana pelaku bisnis harus menjalankan sesuatu dengan jujur, gigih, ulet dan mampu berkompetisi dengan sehat.

Dengan bahasa lain bahwa integritas dalam bisnis akan membawa kebaikan bagi pelaku bisnisnya, hal ini selaras dengan hadist Rosulallah SAW bahwa "Sesungguhnya shidq mengantarkan pada kebaikan dan kebaikan akan mengantarkan kedalam surga. Seseorang yang selalu berusaha untuk shidq akan dicatat oleh Allah SWTsebagai orang shiddiq dan jauhilah oleh kamu perbuatan dusta ,karena dusta akan mengantarkan pada kejahatan. Dan kejahatan akan mengantar kedalam neraka. Seorang yang selalu berdusta akan dicatat oleh Allah sebagai pendusta (HR. Bukhari)."

\section{Aplikasi sifat shiddiq dalam bisnis}

Hilangnya nilai-nilai integritas atau kejujuran menyebabkan tidakadarasa tentram di masyarakat.Dalam kegiatan bisnis integritas atau kejujuran mendapatkan prioritas utama. Salah satu sikap mulia yang lekat dan paling menonjol pada kepribadian Nabi Muhammad SAW adalah shiddiq (integritas, kejujuran), dengan sifat ini diganjar dengan julukan alamin oleh masyarakat setempat (shihab, 2017:136), dengan sifat ini juga Nabi Muhammad SAW berhasil sebagai seorang entrepreneur. 
Nabi Muhammad SAW telah memberikan teladan praktek shiddiq (integritas, kejujuran) dalam segala aspek kehidupan, termasuk dalam kegiatan berbisnis. Dalam prakteknya masyarakat lebih menonjolkan barang dagangannya dan menyembunyikan cacatnya, hal ini merupakan penipuan (curang) sebagai lawan kata dari shiddiq (integritas, kejujuran).

Pada penelitian Irawan (2017: 80) yang berjudul "Penerapan Etika Bisnis Islam pada Pedagang Sembako di Pasar Sentral Sinjai" melakukan wawancara dengan penjual sebagai berikut; "satu memang kepuasan tersendiri bagi kita selaku pembeli, dan merasa tidak dibodoh-bodohi penjual, bila mana mereka transparan memperlihatkan cara mereka menjual termasuk cara menimbang barang, sehingga dalam membeli barang sembako tidak ada memang perasaan untuk berpindah ke pedagang yang lain karena kita terpuaskan."Kegiatan bisnis pada pedagang sembako tersebut, penjual wajib memprioritaskan sifats hiddiq (integritas, kejujuran) sebagai sebagai bentuk tanggungjawab kepada penbeli.

\section{PENUTUP}

Sifat shiddiq masih sangat relevan dengan etika binis moderen. Sifat shiddiq (integritas, kejujuran) berarti melandaskan ucapan, keyakinan serta perbuatan berdasarkan ajaran Islam.Dengan demikian sifat shiddiq (integritas, kejujuran) merupakan etika bisnis yang universal dan tidak mengenal nilai dasar yang melatarbelakangi etika tersebut

\section{DAFTAR PUSTAKA}

Adinugraha, Hendri Hermawan, Norma Dan Nilai Dalam IImu Ekonomi Islam, Jurnal Media Ekonomi dan Teknologi Informasi. 2013.

Afzalurrahman.Muhammad Sebagai Pedagang. Jakarta: Yayasan Swarna Bhumy, 2000.

Al-Munadi, Shiddiq dalam Pandangan Quraish Shihab, Jurnal JIA. 2016.

Fauzia, Ika Yunia. Etika Bisnis dalam Islam. 2013. Jakarta: Kencana.

Hulaimi,Ahmad dkk.EtikaBisnis Islam Dan DampaknyaTerhadapKesejahteraanPedagangSapi, JurnalEkonomidanBisnis Islam (JEBI), 2017.

Idri, HadistEkonomi (EkonomiDalamPerspektif Islam HadistNabi).Cet.I. Jakarta: Kencana, 2015.

Irawan, Heri. PenerapanEtikaBisnis Islam PadaPedagangSembako di PasarSentralSinjai, Tesis UIN AlauddinMakasar, 2017.

Khaeriyah, HamzahHasan. Fiqhlqtishad, Ekonomi Islam, KerangkaDasar, StudiTokohdanKelembagaanEkonomi. Makasar: Alauddin University Press, 2013.

Malahayati. Rahasia Sukses Bisnis Rasulullah. Yogyakarta: Jogja Great Publisher, 2010.

Mardatillah, Annisa. Etika Bisnis dalam Perspektif Islam, Jurnal JIS, 2013

Qordhawi, Yusuf.Norma dan Etika Ekonomi Islam. Jakarta: Gema Insani Press, 1997.

Shihab, Muhammad Quraish. Tafsir al-Misbah (Pesan, Kesan dan Keserasian Al-Qur'an), Jakarta, Lentera Hati, 2007.

Sitepu, Novi Indriyani.Prilaku Bisnis Muhammad Saw Sebagai Entrepreneur dalam Filsafat Ekonomi Islam. Jurnal Human Falah, 2016. 